\title{
Gambaran Faktor Risiko dan Tipe Stroke pada Pasien Rawat Inap di Bagian Penyakit Dalam RSUD Kabupaten Solok Selatan Periode 1 Januari 2010 - 31 Juni 2012
}

\author{
Cintya Agreayu Dinata, Yuliarni Syafrita, Susila Sastri
}

\begin{abstract}
Abstrak
Stroke merupakan penyakit akibat gangguan peredaran darah otak yang dipengaruhi oleh banyak faktor risiko terdiri dari yang tidak dapat diubah berupa usia dan jenis kelamin dan yang dapat diubah seperti hipertensi, peningkatan kadar gula darah, dislipidemia, dan pekerjaan. Penelitian ini bertujuan untuk mengetahui distribusi tipe stroke dan faktor risiko yang berpengaruh pada pasien stroke rawat inap di RSUD Kabupaten Solok Selatan. Metode penelitian: Penelitian ini adalah penelitian deskriptif dengan menggunakan data skunder pasien stroke yang dirawat di RSUD Solok Selatan. Data yang diambil meliputi usia, jenis kelamin, tekanan darah, kadar gula darah, profil lipid saat pertama pasien masuk rumah sakit, dan pekerjaan. Sampel penelitian adalah seluruh pasien stroke yang pernah dirawat di Bagian Penyakit Dalam RSUD Kabupaten Solok Selatan pada periode 1 Januari 2010 - 31 Juni 2012 yang memenuhi kriteria inklusi. Hasil penelitian: Hasil penelitian menunjukkan proporsi stroke terbanyak adalah stroke ischemic $(61,46 \%)$, perempuan $(54,17 \%)$ yang berusia $>50$ tahun $(81,25 \%)$ yang bekerja sebagai ibu rumah tangga $(43,75 \%)$. Faktor risiko yang dapat diubah tertinggi adalah hipertensi $(82,30 \%)$ diikuti kolesterol total meningkat $(69,79 \%)$. Faktor risiko tertinggi pada stroke ischemic adalah gula darah meningkat $(47,89 \%)$ dan pada stroke hemorrhagic adalah hipertensi (100,00\%). Faktor risiko tertinggi pada seluruh pasien adalah hipertensi $(82,30 \%)$. Kesimpulan: Berdasarkan hasil penelitian ini disimpulkan bahwa stroke tipe ischemic lebih banyak dari tipe hemorrhagic dengan faktor risiko utama hipertensi, sedangkan stroke ischemic terutama dipengaruhi oleh peningkatan gula darah.
\end{abstract}

Kata kunci: stroke ischemic, stroke hemorrhagic, faktor risiko stroke

\begin{abstract}
Stroke is a disease caused by disorder of brain blood circulation with many risk factors that contribute in this disease, consist of non modifiable risk factor including age and sex and modifiable risk factors example hypertension, high glucose level, dyslipidemia, and jobs. This study aimed to determine the distribution of the type of stroke and the risk factors that affect to stroke patients who were treat in South Solok hospital.Methods: This research is descriptive research using secondary data, including the patient's medical record. The data including age, gender, blood pressure, glucose level, lipid profile when the first patient in the hospital, and jobs. The samples were all stroke patients who had been treat in the Department of Internal Medicine of South Solok hospital in the period from January 1st 2010 until June 31th 2012 that meet the inclusion criteria. The results: The results showed the highest proportion of strokes were ischemic stroke (61.46\%), women (54.17\%) aged> 50 years (81.25\%) who work as housewives (43.75\%). The highest of modifiable risk factors are hypertension (82.30\%) followed by increases in total cholesterol (69.79\%). The highest risk factors for ischemic stroke is high glucose level (47.89\%) and for hemorrhagic stroke is hypertension (100.00\%). The highest risk in both ischemic stroke and hemorrhagic is hypertension (82.30\%).Conclusion: Based on the end result, we can concluded that the insidence of ischemic stroke disease is greater than hemorrhagic stroke, and as the main risk factor is hypertension, mean while ischemic stroke is most affected by high glucose level.
\end{abstract}

Keywords: stroke ischemic, stroke hemorrhagic, faktor risiko stroke

Affiliasi penulis : Arial 7 Cintya Agreayu Dinata,

Korespondensi : Fakultas Kedokteran Universitas Andalas, email : yutsu_miracle30@roketmail.com Telp/hp : 085274225417

\section{Pendahuluan}

Stroke merupakan penyakit terbanyak ketiga setelah penyakit jantung dan kanker, serta merupakan penyakit penyebab kecacatan tertinggi di dunia. Menurut American Heart Association (AHA), angka kematian penderita stroke di Amerika setiap tahunnya adalah $50-100$ dari 100.000 orang penderita. ${ }^{1,2}$

Di negara-negara ASEAN penyakit stroke juga merupakan masalah kesehatan utama yang menyebabkan kematian. Dari data South East Asian Medical Information Centre (SEAMIC) diketahui bahwa angka kematian stroke terbesar terjadi di Indonesia yang kemudian diikuti secara berurutan oleh Filipina, Singapura, Brunei, Malaysia, dan Thailand. Dari seluruh penderita stroke di Indonesia, stroke ischemic merupakan jenis yang paling banyak diderita yaitu sebesar 52,9\%, diikuti secara berurutan oleh perdarahan intraserebral, emboli dan perdarahan subaraknoid dengan angka kejadian masingmasingnya sebesar $38,5 \%, 7,2 \%$, dan $1,4 \%{ }^{2}$

Stroke atau yang dikenal juga dengan istilah Gangguan Peredaran darah Otak (GPDO), merupakan suatu sindrom yang diakibatkan oleh adanya gangguan aliran darah pada salah satu bagian otak yang menimbulkan gangguan fungsional otak berupa defisit neurologik atau kelumpuhan saraf. ${ }^{3}$ 
Stroke disebabkan oleh keadaan ischemic atau proses hemorrhagic yang seringkali diawali oleh adanya lesi atau perlukaan pada pembuluh darah arteri. Dari seluruh kejadian stroke, duapertiganya adalah ischemic dan sepertiganya adalah hemorrhagic. Disebut stroke ischemic karena adanya sumbatan pembuluh darah oleh thromboembolic yang mengakibatkan daerah di bawah sumbatan tersebut mengalami ischemic. Hal ini sangat berbeda dengan stroke hemorrhagic yang terjadi akibat adanya mycroaneurisme yang pecah., ${ }^{4,5}$

Faktor yang dapat menimbulkan stroke dibedakan menjadi faktor risiko yang tidak dapat diubah atau tidak dapat dimodifikasi dan faktor risiko yang dapat diubah atau dapat dimodifikasi. ${ }^{6}$

Faktor risiko yang tidak dapat diubah diantaranya peningkatan usia dan jenis kelamin lakilaki. ${ }^{6}$

Faktor risiko yang dapat diubah antara lain hipertensi, diabetes melitus, dan dislipidemia. Hipertensi diartikan sebagai suatu keadaan dimana tekanan darah seseorang melebihi batas tekanan darah normal. Hipertensi merupakan faktor risiko yang potensial pada kejadian stroke karena hipertensi dapat mengakibatkan pecahnya pembuluh darah otak atau menyebabkan penyempitan pembuluh darah otak. Pecahnya pembuluh darah otak akan mengakibatkan perdarahan otak, sedangkan jika terjadi penyempitan pembuluh darah otak akan mengganggu aliran darah ke otak yang pada akhirnya menyebabkan kematian sel-sel otak.

Klasifikasi tekanan darah menurut JNC VII

\begin{tabular}{llrl}
\hline Kategori & Sistolik & Diastolik \\
\hline $\begin{array}{l}\text { Normal } \\
\begin{array}{l}\text { Prehipertensi } \\
\text { Hipertensi }\end{array}\end{array}$ & $<120$ & Dan $<80$ \\
& & & \\
& & & \\
Derajat I & $140-159$ & Atau & $90-99$ \\
Derajat II & $\geq 160$ & Atau & $\geq 100$ \\
& & & \\
\hline
\end{tabular}

Diabetes melitus adalah suatu keadaan yang ditandai dengan hiperglikemia yang terjadi karena adanya gangguan sekresi insulin atau kerja insulun ataupun keduanya, dan termasuk suatu kelompok penyakit metabolik. Diagnosis diabetes melitus ditegakkan jika konsentrasi darah sewaktu (plasma vena) $\geq 200 \mathrm{mg} / \mathrm{dl}$ atau konsentrasi glukosa darah puasa $>126 \mathrm{mg} / \mathrm{dl}$ atau konsentrasi glukosa darah $>200 \mathrm{mg} / \mathrm{dl}$ pada 2 jam sesudah beban glukosa 75 gram pada TTGO (Tes Toleransi Glukosa Oral). Diabetes melitus menyebabkan stroke melalui kemampuannya menebalkan pembuluh darah otak yang berukuran besar. Penebalan tersebut akan mengakibatkan diameter pembuluh darah mengecil yang akhirnya menyebabkan gangguan aliran darah ke otak yang berujung pada kematian sel-sel otak. ${ }^{1,8,9}$

\begin{tabular}{lllll}
\hline $\begin{array}{l}\text { Kompon } \\
\text { en }\end{array}$ & $\begin{array}{l}\text { Koles } \\
\text { terol }\end{array}$ & LDL & HDL & $\begin{array}{l}\text { Trig } \\
\text { liserida }\end{array}$ \\
\cline { 1 - 3 } $\begin{array}{l}\text { Kadar } \\
\text { Normal }\end{array}$ & $\begin{array}{l}<200 \\
\mathrm{mg} / \mathrm{dl}\end{array}$ & $\begin{array}{l}<\mathrm{mg} / \mathrm{dl} \\
\mathrm{m}\end{array}$ & $>35$ & $\begin{array}{l}<200 \\
\mathrm{mg} / \mathrm{dl}\end{array}$
\end{tabular}

Sumber : Pinzon et al, 2010

Kolesterol LDL berfungsi membawa kolesterol dari hati ke dalam sel. Jika kadar kolesterol ini tinggi dapat mengakibatkan terjadinya penimbunan kolesterol di dalam sel yang dapat memicu terjadinya pengerasan dinding pembuluh darah arteri yang disebut sebagai proses atherosklerosis. Sedangkan kolesteol HDL memiliki kerja yang berlawanan dengan kolesterol LDL, yaitu membawa kolesterol dari sel ke hati. Kadar HDL yang rendah justru memiliki efek buruk, memicu timbulnya pembentukan plak di dinding pembuluh darah arteri. ${ }^{6}$

\section{Metode}

Penelitian dilakukan di Instalasi Rekam Medis dan Bagian Penyakit Dalam RSUD Kabupaten Solok Selatan, Sumatera Barat pada bulan November 2011 Januari 2013. Populasi penelitian adalah semua pasien stroke yang pernah dirawat di Bagian Penyakit Dalam RSUD Kabupaten Solok Selatan, Sumatera Barat pada periode 1 Januari 2010 - 31 Juni 2012 yang mempunyai data rekam medik yang lengkap meliputi usia, jenis kelamin, tekanan darah, kadar gula darah, profil lipid, dan pekerjaan. Jumlah pasien stroke yang pernah dirawat adalah sebanyak 120 orang, tetapi hanya 96 yang memiliki data rekam medik lengkap yang dapat dimasukkan dalam penelitian. Sampel penelitian adalah semua populasi penelitian.

\section{Hasil dan Pembahasan}

a. Klasifikasi stroke

Tabel 1. Distribusi pasien stroke menurut tipe stroke pada pasien rawat inap di Bagian Penyakit Dalam RSUD Kabupaten Solok Selatan periode 1 Januari 2010 - 31 Juni 2012

\begin{tabular}{lll}
\hline Tipe Stroke & $\begin{array}{l}\text { Jumlah } \\
\text { Pasien }\end{array}$ & $\begin{array}{l}\text { Persentase } \\
(\%)\end{array}$ \\
\hline Ischemic & 59 & 61,46 \\
Hemorrhagic & 37 & 38,54 \\
\hline Jumlah & $\mathbf{9 6}$ & $\mathbf{1 0 0 , 0 0}$ \\
\hline
\end{tabular}

Pada tabel diatas dapat dilihat bahwa tipe stroke ischemic $(61,46 \%)$ lebih banyak dibandingkan stroke hemorrhage $(38,54 \%)$. Hasil ini sesuai dengan berbagai tinjauan pustaka dan penelitian yang telah dilakukan sebelumnya. Berdasarkan penelitian yang dilakukan oleh Alijan Ahmadi Ahanger dan kawankawan di Yahyanejad Hospital Babol, Iran bagian utara dari April 2001 - April 2003 didapatkan kasus stroke ischemic lebih banyak dibandingkan stroke hemorrhagic dengan persentase masing-masingnya $67,2 \%$ dan $32,8 \%$.

Berdasarkan penelitian yang dilakukan di Rumah Sakit Krakatau Medika periode 1 Januari - 31 Desember 2011 oleh Dian Nastiti juga didapatkan hasil yang sama, stroke ischemic lebih banyak 
dibandingkan stroke hemorrhagic, yangmana dari 152 pasien, $85 \%$ penderita stroke ischemic dan hanya $15 \%$ penderita stroke hemorrhagic.

\section{b. Faktor Risiko yang Tidak Dapat Diubah 1. Usia}

Tabel 2. Distribusi pasien stroke menurut usia pada pasien rawat inap di Bagian Penyakit Dalam RSUD Kabupaten Solok Selatan periode 1 Januari 2010 - 31 Juni 2012.

\begin{tabular}{lccc}
\hline $\begin{array}{l}\text { Usia } \\
\text { (tahun) }\end{array}$ & \multicolumn{2}{c}{$\begin{array}{c}\text { Tipe Stroke } \\
\text { Ischemic }\end{array}$} & $\begin{array}{l}\text { Total } \\
(\%)\end{array}$ \\
\hline $\mathbf{5 0 0}$ & 15 & $3(3,12 \%)$ & 18 \\
& $(15,63 \%)$ & & $(18,75)$ \\
$>\mathbf{5 0}$ & 44 & $34(35,42 \%)$ & 78 \\
& $(45,83 \%)$ & & $(81,25)$ \\
\hline Jumlah & & & 96 \\
& & & $(100,00)$ \\
\hline
\end{tabular}

Pada tabel diatas dapat dilihat bahwa lebih dari $50 \%$ penderita berusia di atas 50 tahun, yaitu dengan persentase $81,25 \%$. Sementara itu, hanya $18,75 \%$ penderita yang berusia di bawah 50 tahun.

Hasil penelitian ini sama dengan hasil penelitian yang dilakukan oleh Mochammad Bahrudin pada tahun 2009 di RSU Haji Surabaya, yangmana didapatkan kejadian tertinggi stroke terjadi pada usia diatas 50 tahun ( $69,7 \%$ ), dan sisanya terjadi pada usia dibawah 50 tahun, dengan puncaknya pada usia 51-60 tahun.

$$
\text { 2. Jenis Kelamin }
$$

Tabel 3. Distribusi pasien stroke menurut jenis kelamin pada pasien rawat inap di Bagian Penyakit Dalam RSUD Kabupaten Solok Selatan periode 1 Januari 2010 - 31 Juni 2012.

\begin{tabular}{lccc}
\hline $\begin{array}{l}\text { Jenis } \\
\text { Kelamın }\end{array}$ & \multicolumn{2}{c}{ Tipe Stroke } & \multicolumn{1}{l}{ Total } \\
Ischemic & Hemorrhagic & $(\%)$ \\
\hline Lk & & & \\
& 28 & 16 & 44 \\
& $(29,17 \%)$ & $(16,66 \%)$ & $(45,83)$ \\
Pr & 31 & 21 & \\
& $(32,29 \%)$ & $(21,88 \%)$ & $(54,17)$ \\
Jumlah & & & 96 \\
& & & $(100,00)$
\end{tabular}

Pada tabel diatas dapat dilihat bahwa angka kejadian stroke pada perempuan lebih tinggi dibandingkan laki-laki, yaitu 52 orang perempuan $(54,17 \%)$ dan 44 orang laki-laki (45,83\%). Meskipun di tinjauan pustaka diungkapkan bahwa risiko terjadinya stroke pada laki-laki lebih tinggi dibandingkan perempuan, namun dari penelitian-penelitian yang dilakukan didapatkan hasil yang beragam.

Berdasarkan penelitian yang dilakukan oleh Chih-Ying Wu dan kawan-kawan pada Maret 2007 Agustus 2008 di Taiwan, didapatkan angka kejadian stroke pada laki-laki lebih tinggi dibandingkan perempuan dengan persentase masing-masingnya $63,4 \%$ laki-laki dan $36.6 \%$.
Namun dalam sebuah penelitian lain yang dilakukan oleh Wolfe dan kawan-kawan di London bagian selatan, dari total pasien stroke sebanyak 1.254 orang didapatkan penderita perempuan lebih banyak dibandingkan laki-laki, yaitu $51,6 \%$ perempuan dan $48,4 \%$ penderita stroke yang berjenis kelamin lakilaki.

Sebuah penelitian pada pasien stroke yang dilakukan oleh Hardi Yanis tahun 2004 di RSUP Dr.Kariadi dengan 66 sampel, juga didapatkan bahwa penderita perempuan $(59,1 \%)$ lebih banyak dibanding laki-laki yang hanya 40,9\%.

c. Faktor Risiko yang Dapat Diubah 1. Hipertensi

Tabel 4. Distribusi pasien stroke menurut faktor risiko hipertensi pada pasien rawat inap di Bagian Penyakit Dalam RSUD Kabupaten Solok Selatan periode 1 Januari 2010 - 31 Juni 2012.

\begin{tabular}{|c|c|c|c|c|}
\hline \multirow{2}{*}{$\begin{array}{l}\text { Tekanan } \\
(\mathrm{mmHg})\end{array}$} & \multirow[t]{2}{*}{ Darah } & \multicolumn{2}{|c|}{ Tipe Stroke } & \multirow{2}{*}{$\begin{array}{l}\text { Total } \\
(\%)\end{array}$} \\
\hline & & Ischemic & $\begin{array}{l}\text { Hemorrh } \\
\text { agic }\end{array}$ & \\
\hline
\end{tabular}

\begin{tabular}{lcll}
\hline Normal & 8 & - & $8(8,33)$ \\
$\begin{array}{l}\text { Prehiper- } \\
\text { tensi }\end{array}$ & $(8,33 \%)$ & & 9 \\
& 9 & - & $(9,37)$ \\
$\begin{array}{l}\text { Hiper- } \\
\text { tensi }\end{array}$ & $49,37 \%)$ & & 79 \\
Jumlah & $(43,76 \%)$ & $(38,54 \%)$ & $(82,30)$ \\
& & & $96(100,00 \%)$
\end{tabular}

Pada tabel diatas dapat dilihat bahwa $82,30 \%$ mempunyai faktor risiko hipertensi (hipertensi derajat 1 dan derajat 2 ).

Sebuah penelitian yang dilakukan di RS Krakatau Medika pada tahun 2011 oleh Dian Nastiti mendapatkan hasil, $46 \%$ dari seluruh pasien stroke yang diteliti, yang merupakan jumlah terbanyak mempunyai faktor risiko hipertensi yang diikuti secara berturut-turut oleh prehipertensi dan tekanan darah normal.

\section{Viabetes IVIelıtus}

Tabel 5. Distribusi pasien stroke menurut faktor risiko gula darah yang meningkat pada pasien rawat inap di sagian renyakı vaiarn noU napupaten soıк Selatan periode 1 Januari 2010 - 31 Juni 2012.

$\begin{array}{llll}\begin{array}{l}\text { Kadar Gula Darah } \\ \text { (mg/dl) }\end{array} & \begin{array}{l}\text { Tipe Stroke } \\ \text { Ischemic }\end{array} & \text { Hemorrhagic } & \text { Total } \\ \text { Normal } & 13 & 15 & 28 \\ & (18,31 \%) & (21,13 \%) & (39,44 \%) \\ \text { Meningkat } & 34 & 9 & 43 \\ & (47,89 \%) & (12,67 \%) & (60,56 \%) \\ \text { Jumlah } & & & 71 \\ & & & (100,00 \%)\end{array}$

Pada tabel diatas dapat dilihat bahwa sebagian besar pasien memiliki faktor risiko kadar gula darah meningkat $(60,56 \%)$.

Diabetes melitus merupakan salah satu faktor risiko stroke yang bisa dimodifikasi. Pada seseorang dengan diabetes melitus, risiko terjadinya stroke 
meningkat dua kali lipat dibandingkan dengan orang tanpa diabetes. ${ }^{6}$ Hal ini terjadi karena peningkatan gula darah dapat meningkatkan risiko atherosklerosis dan juga risiko stroke lainnya seperti hipertensi, obesitas, dan hyperlipidemia. ${ }^{8,10}$

$$
\text { 3. Dislipidemia }
$$

Tabel 6. Distribusi pasien stroke menurut faktor risiko LDL pada pasien rawat inap di Bagian Penyakit Dalam RSUD Kabupaten Solok Selatan periode 1 Januari 2010 - 31 Juni 2012.

\begin{tabular}{llll}
\hline Kadar LDL & $\begin{array}{l}\text { Tipe Stroke } \\
\text { Ischemic }\end{array}$ & $\begin{array}{l}\text { Hemorha } \\
\text { gic }\end{array}$ & Total \\
Normal & $17(17,71 \%)$ & 16 & 33 \\
& & $(16,67 \%)$ & $\begin{array}{l}(34,37 \\
\%)\end{array}$ \\
& & & \\
Meningkat & $42(43,75 \%)$ & 21 & 63 \\
& & $(21,87 \%)$ & $\begin{array}{l}(65,63 \\
\%)\end{array}$ \\
& & & 96 \\
Jumlah & & & $(100,0)$ \\
& & & \\
\hline
\end{tabular}

Pada tabel diatas dapat dilihat bahwa sebagian besar pasien memiliki kadar LDL yang meningkat $(65,63 \%)$.

Tabel 7. Distribusi pasien stroke menurut faktor risiko HDL pada pasien rawat inap di Bagian Penyakit Dalam RSUD Kabupaten Solok Selatan periode 1 Januari 2010 - 31 Juni 2012.

\begin{tabular}{llll}
\hline Kadar HDL & $\begin{array}{l}\text { Tipe Stroke } \\
\text { Ischemic }\end{array}$ & $\begin{array}{l}\text { Hemorrha } \\
\text { gic }\end{array}$ & Total \\
Normal & $24(25,00 \%)$ & $\begin{array}{l}25 \\
(26,04 \%)\end{array}$ & $\begin{array}{l}49 \\
(51,04 \%)\end{array}$ \\
& & & \\
Meningkat & $35(36,46 \%)$ & $\begin{array}{l}12 \\
(12,50 \%)\end{array}$ & $\begin{array}{l}(48,96 \%) \\
\end{array}$ \\
Jumlah & & & 96 \\
& & & $(100,00)$
\end{tabular}

Pada tabel diatas dapat dilihat bahwa, pasien dengan faktor risiko HDL normal lebih banyak $(51,04 \%)$

Tabel 8. Distribusi pasien stroke menurut faktor risiko trigliserida pada pasien rawat inap di Bagian Penyakit Dalam RSUD Kabupaten Solok Selatan periode 1 Januari 2010 31 Juni 2012.

\begin{tabular}{|c|c|c|c|}
\hline Kadar & Tipe Stroke & & Total \\
\hline Trigliserida & Ischemic & Hemorrhagic & \\
\hline Normal & $\begin{array}{l}18 \\
(18,75 \%)\end{array}$ & $\begin{array}{l}16 \\
(16,67 \%)\end{array}$ & $\begin{array}{l}34 \\
(35,42 \%)\end{array}$ \\
\hline Meningkat & $\begin{array}{l}41 \\
(42,71 \%)\end{array}$ & $\begin{array}{l}21 \\
(21,87 \%)\end{array}$ & $\begin{array}{l}62 \\
(64,58 \%)\end{array}$ \\
\hline Jumlah & & & $\begin{array}{l}96 \\
(100,00 \%)\end{array}$ \\
\hline
\end{tabular}

Pada tabel diatas dapat dilihat bahwa, sebagian besar pasien memiliki kadar trigliserida yang meningkat $(64,58 \%)$.

Tabel 9. Distribusi pasien stroke menurut faktor risiko kolesterol total pada pasien rawat inap di Bagian Penyakit Dalam RSUD Kabupaten Solok Selatan periode 1 Januari $2010-31$ Juni 2012

\begin{tabular}{llll}
\hline $\begin{array}{l}\text { Kadar } \\
\text { Kolesterol Total }\end{array}$ & $\begin{array}{l}\text { Tipe Stroke } \\
\text { Ischemic }\end{array}$ & $\begin{array}{l}\text { Hemorrhagi } \\
c\end{array}$ & Total \\
Normal & $15(15,63 \%)$ & $\begin{array}{l}14 \\
(14,58 \%)\end{array}$ & $\begin{array}{l}29 \\
(30,21 \%)\end{array}$ \\
& & & 67 \\
Meningkat & $44(45,83 \%)$ & $\begin{array}{l}23 \\
(23,96 \%)\end{array}$ & $(69,79 \%)$ \\
& & & 96 \\
Jumlah & & & $(100,00 \%)$ \\
& & &
\end{tabular}

Pada tabel diatas dapat dilihat bahwa, sebagian besar pasien memiliki kadar kolesterol meningkat $(69,79 \%)$.

LDL membawa kolesterol dari hati ke sel-sel. Jika kadarnya tinggi akan mengakibatkan terjadinya penumpukan kolesterol di dinding pembuluh darah dan memicu terjadinya pengerasan dinding pembuluh darah yang berujung pada atherosklerosis. Sementara itu, HDL perannya adalah sebagai pembawa kolesterol dari sel-sel tubuh kembali ke hati, dapat membersihkan penimbunan kolesterol yang terjadi pada pembuluh darah, sehingga dapat mencegah terjadinya atherosklerosis.

Trigliserida merupakan lemak utama dalam makanan. Setelah sampai di usus, trigliserida akan dikemas dalam bentuk kilomikron dan VLDL, kemudian diangkut lewat darah. Saat trigliserida dicerna oleh lipoprotein lipase, kilomikron diubah menjadi sisa kilomikron sedangkan VLDL diubah menjadi bentuk IDL. IDL selanjutnya diurai menjadi bentuk LDL.
d. Faktor Risiko Tertinggi pada Semua Pasien Stroke

Tabel 10. Distribusi pasien stroke menurutfaktor risiko tertinggi pada pasien rawat inap di Bagian Penyakit Dalam RSUD Kabupaten Solok Selatan periode 1 Januari 2010 - 31 Juni 2012.

\begin{tabular}{lll}
\hline Faktor Risiko & $\left.\begin{array}{l}\text { Persentase } \\
\%\end{array}\right)$ & $\begin{array}{l}\text { Peringk } \\
\text { at }\end{array}$ \\
Hipertensi & 82,30 & 1 \\
Usia ( $>50$ tahun ) & 81,25 & 2 \\
Kolesterol total & 69,79 & 3 \\
LDL & 65,63 & 4 \\
Trigliserida & 64,58 & 5 \\
Gula darah meningkat & 60,56 & 6 \\
Jeniskelamin (perempuan) & 54,17 & 7 \\
HDL & 48,96 & 8 \\
\hline
\end{tabular}


Pada tabel disamping dapat dilihat bahwa faktor risiko tertinggi yang dimiliki oleh 96 pasien stroke yang diteliti, baik faktor risiko yang dapat diubah maupun yang tidak dapat diubah adalah hipertensi $(82,30 \%)$.

\section{e. Faktor Risiko Tertinggi pada Tipe Stroke}

Tabel 11. Distribusi faktor risiko tertinggi pada masingmasing tipe stroke pada pasien rawat inap di Bagian Penyakit Dalam RSUD Kabupaten Solok Selatan periode 1 Januari 2010 - 31 Juni 2012.

\begin{tabular}{lllll}
\hline Faktor Risiko & \multicolumn{2}{l}{ Ischemia } & \multicolumn{2}{l}{ Hemorrhagic } \\
& $\begin{array}{l}\text { Perin } \\
\text { gkat }\end{array}$ & $\begin{array}{l}\text { Persenta } \\
\text { se (\%) }\end{array}$ & $\begin{array}{l}\text { Persent } \\
\text { ase (\%) }\end{array}$ & $\begin{array}{l}\text { Perin } \\
\text { gkat }\end{array}$ \\
Gula darah meningkat & 1 & 47,89 & 12,67 & 6 \\
Kolesterol total & 2 & 45,83 & 23,96 & 3 \\
Usia (> 50 tahun ) & 2 & 45,83 & 35,42 & 2 \\
Hipertensi & 3 & 43,76 & 100,00 & 1 \\
LuL & 4 & $43, / 5$ & $21,8 /$ & 5 \\
$\begin{array}{l}\text { Trigliserida } \\
\text { HDL }\end{array}$ & 5 & 42,71 & 21,87 & 5 \\
$\begin{array}{l}\text { Jenis } \\
\text { perempuan }\end{array}$ & 6 & 36,46 & 12,50 & 7 \\
\hline
\end{tabular}

Pada tabel diatas dapat dilihat bahwa, faktor risiko tertinggi yang dimiliki oleh pasien stroke ischemic adalah gula darah meningkat (47,89\%). Sedangkan pada pasien stroke hemorrhagic, faktor risiko tertingginya adalah hipertensi (100,00\%).

\section{Kesimpulan}

Berdasarkan penelitian yang dilakukan ini, didapatkan kesimpulan sebagai berikut :

1. Tipe stroke yang paling banyak diderita pasien adalah stroke ischmic $(61,46 \%)$.

2. Pasien terbanyak berusia diatas 50 tahun $(81,25 \%)$ dan berjenis kelamin perempuan $(54,17 \%)$.

3. Sebagian besar pasien memiliki faktor risiko hipertensi (82,30\%), kadar gula darah meningkat $(63,54 \%)$, LDL meningkat $(65,63 \%)$, trigliserida meningkat $(64,58 \%)$, dan kolesterol total meningkat $(69,79 \%)$. Pasien dengan kadar HDL normal lebih banyak $(51,04 \%)$ dibandingkan yang tidak normal $(48,96 \%)$. Sebagian besar pasien bekerja sebagai ibu rumah tangga $(43,75 \%)$.

4. Faktor risiko tertinggi pada semua pasien adalah hipertensi (82,30\%), pada pasien dengan stroke ischemic kadar gula darah meningkat $(47,89 \%)$, sedangkan pada pasien stroke hemorrhagic adalah hipertensi $(100,00 \%)$

\section{Daftar Pustaka}

1. Permatasari, Dwita. 2011. Kejadian Hiperkolesterolemia Disertai Hipertensi dan Diabetes Mellitus pada Penderita Stroke Trombotik Akut. Bulletin Penelitian RSUD Dr Soetomo, 13(3), 112-120.

2. A, Basjiruddin ; darwin Amir (ed.). 2008. Buku Ajar IImu Penyakit Saraf (Neurologi) edisi 1. Bagian IImu Penyakit Saraf Fakultas Kedokteran Universitas Andalas.

3. Gustaviani, Reno. 2007. Diagnosis dan Klasifikasi Diabetes Melitus. Dalam (Sudoyo, Aru W; Bambang Setiyohadi; Idrus Alwi; Marcellus Simadibrata K; Siti Setiadi. ed.). Buku Ajar IImu Penyakit Dalam jilid 3, edisi 4. Jakarta: Pusat Penerbitan Departemen Imu Penyakit Dalam Fakultas Kedokteran Universitas Indonesia. Hal 1857-1859.

4. Guyton, Arthur C; John E Hall. 2007. Textbook of Medical Physiology edisi 11. Terjemahan; Dian Ramadhani; Fara Indriyani; Frans Dany; Imam Ivuryarıto; srıe sısca rrırna kianı; I ıек Resmisari; Joko Suryono. 2008. Buku Ajar Fisiologi Kedokteran edisi 11. Jakarta: EGC.

5. Hananta, I Putu Yuda; Harry Freitag L.M. 2011. Deteksi Dini dan Pencegahan Hipertensi dan Stroke. Yogyakarta: Media Pressindo.

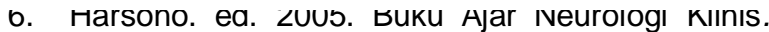
Yogyakarta: Gadjah Mada University Press.

7. Marks, Dawn B; Marks, Allan D; Smith, Collen M. 2000. Basic Medical Biochemistry : A Clinical Approach. Terjemahan; Brahm U. Pendit. Biokimia Kedokteran Dasar Sebuah Pendekatan Klinis. Jakarta: EGC.

8. Nastiti, Dian. 2012. Gambaran Faktor Risiko Kejadian Stroke pada pasien Stroke Rawat Inap di Rumah Sakit Krakatau Medika Tahun 2011. Skripsi, Universitas Indonesia.

9. Pinzon, Rizaldy; Laksmi Asanti. 2010. Awas Stroke!. Yogyakarta: ANDI.

10. Purnamasari, Dyah. 2009. Diagnosis dan Klasifikasi Diabetes Melitus. Dalam ( Sudoyo, Aru W; Bambang Setiyohadi; Idrus Alwi; Marcellus Simadibrata K; Siti Setiadi. ed.). Buku Ajar Ilmu Penyakit Dalam jilid 3, edisi 5. Jakarta: InternaPublishing. Hal 1880-1883.

11. Simon, Roger P; David A Greenberg; Michael J Aminoff. 2009. Clinical Neurology edisi internasional 7. USA: McGraw-Hill.

12. Turner, Christopher. 2009. Neurology. China: Mosby Elsevier. 